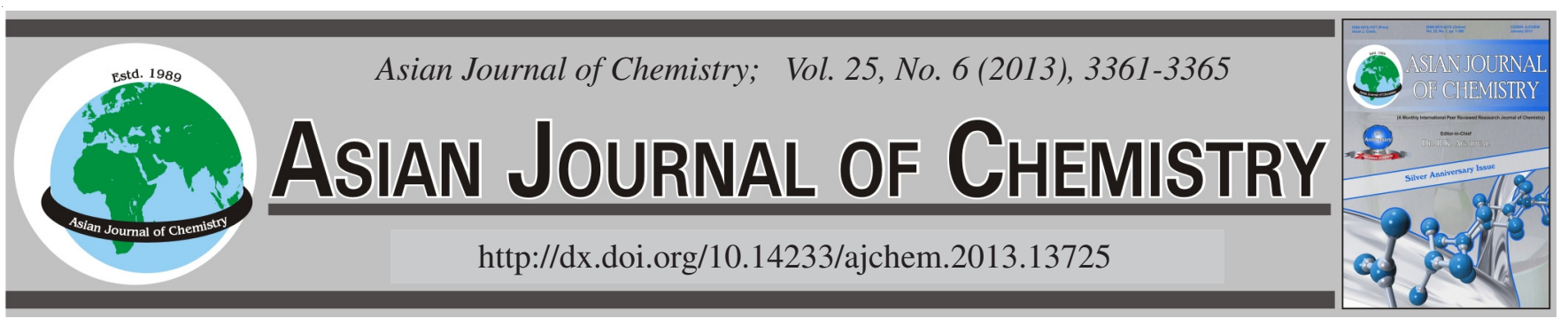

\title{
Separation, Antioxidant and Antimicrobial Activities of Chemical Constituents from Exocarp of Juglans mandshurica Maxim
}

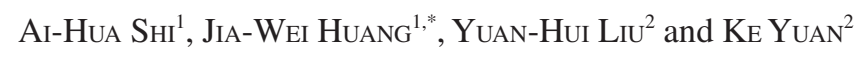

${ }^{1}$ College of Pharmacy, Zhejiang Chinese Medical University, Zhejiang 310053, P.R. China

${ }^{2}$ Zhejiang Agriculture and Forestry University, Lin'an, 311300, P.R. China

*Corresponding author: Tel: +86 571 86613657; E-mail:hjw3657@163.com

\begin{abstract}
This paper reports, the studies of the chemical constituents and antioxidant and antimicrobial activities from exocarp of Juglans mandshurica Maxim. The compounds were isolated by Diaion HP-20, Sephadex LH-20 and MCI CHP-20 column chromatography methods, their structures were identified by physicochemical properties and spectroscopic analysis. Twelve compounds were elucidated as 5-hydroxy-7methoxy sylflavanone (1), chrysophanol (2), juglone (3), 4-hydroxy-cinnamic acid methylester (4), 5,7-dihydroxy-sylflavanone (5), vanillin (6), kaempferol (7), vanillic acid (8), chlorogenic acid (9), cinnamic acid (10), 4-hydroxy-3-methoxy benzyl- $\beta$-D-glucoside (11), 4-hydroxy-cinnamic acid ethylester (12). Meanwhile, the effect of scavenging free radicals of twelve compounds were assayed by using | the DPPH- method with Trolox as control to evaluate their antioxidant capacities. Gram-positive (Staphyloccocus aureus) and gramnegative (Escherichia coli) were selected as the indicator microorganisms to evaluate the antimicrobial activity. Antimicrobial properties were estimated by the agar diffusion method. All of the compounds possessed certain antioxidant and antimicrobial activities.
\end{abstract}

Key Words: Exocarp of Juglans mandshurica Maxim, Chemical constituents.

\section{INTRODUCTION}

Juglans mandshurica Maxim belongs to Juglans Linn of Juglandaceae. It is mainly produced in areas of Lin An, Chun An and Anji counties in Zhejiang Province ${ }^{1}$. When the Juglans mandshurica Maxim is not ripe, there is a thick layer of green peel outside its stone. With its ripening process and its peelingoff after picking, the colour of its epicarp will gradually become brownish red. The epicarp amount of the peeled pecan is great and the weight ratio of its fruit and its peel is equal to $1: 1$, which means a big waste if we throw its peels. According to the literature ${ }^{2}$, the pecan leaves, barks and epicarps can all be used in medicines. The pecan barks have the characteristics of bitterness, pungency, coolness and they can be used in clearing heat, eliminating dampness, purging intestines and killing parasitic worms. In recent years, they are used in treating the diseases of digestive system, tumors, especially in curing esophagus cancer and gastric cancer ${ }^{3}$. From the literature retrieval, we know that there have been some reports on the research of the chemical composition in the pecan barks and leaves, but for the research of the chemical composition and its antibiosis and antioxidation, there are only reports of antibacteria and antioxidation through using crude extracts. As for the separation of the chemical composition in the epicarp of the pecans and the research of the antibiosis and antioxidation of the monomer compounds obtained from the chemical separation, there have been no reports in the literature up till now. In order to understand the material basis of its medicinal activity in the pecan epicarp and to provide scientific data for its comprehensive development, this experiment makes a study on the chemical composition and in vitro antioxidation and antimicrobial of the pecan epicarp. We separate and determine 12 monomer compounds. Twelve compounds were elucidated as 5-hydroxy-7- methoxy sylflavanone (1), chrysophanol (2), juglone (3), 4-hydroxy-cinnamic acid methylester (4), 5,7-dihydroxy-sylflavanone (5), vanillin (6), kaempferol (7), vanillic acid (8), chlorogenic acid (9), cinnamic acid (10), 4-hydroxy-3-methoxy benzyl- $\beta$-D-glucoside (11), 4-hydroxy-cinnamic acid ethylester (12). The compounds 8-12 were isolated from Juglans mandshurica Maxim for the first time. The compounds 6-12 were isolated from the plant for the first time. Meanwhile, the author of thesis determines the in vitro antibiosis and antioxidation activity for the newlyobtained 12 monomer compounds and provides the reference data for its resource.

\section{EXPERIMENTAL}

WRS-1B digital melting-point determinator (Shanghai Precision Scientific Instrument Corp, Ltd., not rectified); Bruker Daltonics Mass Spectrometer; Bruker DPX-400 NMR 
(nuclear Magnetic Resonance) (TMS is its interior label); vacuum thin film concentration Device (self-made) ${ }^{4}$; Rotating Evaporation Instrument (Shanghai Rongya Biotechnology Corp.); Column Chromatography Fillers, Diaion HP-20, MCIGel CHP-20, Toyopearl HW-40 are all the products of Japan Mitsubishi Corp.; Column Chromatography Silica Gel (200300 eyes) and $\mathrm{GF}_{254}$ are all the products made in Qingdao Marine Chemical Factory; the testing reagents are all analytical ethanol.

Infinite M 200 Microplate Reader (Swiss Tecan); UV-2102 PCS Ultraviolet and Visible Spectrometer (Shanghai Unica Instrument Corp.); 101-3 Electric Heating Blast Constant Temperature Drying Oven (Hangzhou Blue Sky Testing Instrument Plant); KQ-250B Ultrasonic Cleaning Device (Kunshan Ultrasonic Instrument Corp.); R201B Rotating Evaporation Instrument (Shanghai Shensheng Biotechnology Corp.).

$\mathrm{Fe}^{3+}$ tripyradyl triazine (TPTZ), 1,1-1,1-diphenyl-2-picrylhydrazyl (DPPH) and 6-hydroxy-2,5,7,8- tetramethychroman2-carboxylic, Trolox are all purchased from sigma corp.

The epicarps of the pecans are picked from Lin'an county, Zhejiang Province and they are identified as the epicarps of Juglans Linn in Juglandaceae by medicine botanical Professor Lou Luhuan, Zhejiang Agriculture and Forestry University.

Extraction and separation: Take $10 \mathrm{~kg}$ of the pecan epicarps and pulverize them into powder after they air-dry naturally at the room temperature. Extract them twice by the cold-soaking method with six times of $70 \% \mathrm{Me}_{2} \mathrm{CO}$. Combine the extracted liquid and get the overall extractum $10 \mathrm{~kg}$ by vacuum-film decompression concentration. Disperse the extractum into the water ultrasonically and extract them by petroleum ether, ethyl acetate, normal butanol, respectively. Concentrate each extracted part by the decompression method and get petroleum ether part (56 g), ethyl acetate part (80 g), normal butanol part (135 g) and water part (360 g). Make a gradient elution for the petroleum part $(56 \mathrm{~g})$ through silica gel column with petroleum ether, petroleum ether-ethyl acetate, ethyl acetate-methanol dissolvants and we will get through separation the compound $\mathbf{3}$ (26 mg), compound $\mathbf{4}$ (36 mg), compound 10 (65 mg), compound 12 (30 mg). Take the obtained ethyl acetate part $(80 \mathrm{~g})$ and disperse it into water, elute it through macroporous adsorbent resin Diaion $\mathrm{Hp}-20$ column with $\mathrm{H}_{2} \mathrm{O}, 10 \% \mathrm{MeOH}, 20 \% \mathrm{MeOH}, 40 \% \mathrm{MeOH}$, $60 \% \mathrm{MeOH}, 70 \% \mathrm{Me}_{2} \mathrm{CO}$, respectively. Among them, elute the $20 \% \mathrm{MeOH}$ part in the Diaion Column through MCI-Gel CHP-20 column chromatography, and repeatedly separate and purify by methanol-water resolvent system, we will get compound 1 (138 mg), compound 2 (120 mg), compound 6 (96 $\mathrm{mg}$ ). Elute the $60 \% \mathrm{MeOH}$ part in the Diaion column through Sephadex LH-20 column chromatography and repeatedly separate and purify by methanol-water resolvent system, we will get compound 5 (180 mg), compound 7 (24 mg), compound $\mathbf{8}(45 \mathrm{mg})$. Take the obtained normal butanol part $(110 \mathrm{~g})$ and disperse it into water, elute it through macroporous adsorbent resin Diaion $\mathrm{Hp}-20$ column with $\mathrm{H}_{2} \mathrm{O}, 10 \% \mathrm{MeOH}$, $20 \% \mathrm{MeOH}, 40 \% \mathrm{MeOH}, 60 \% \mathrm{MeOH}, 70 \% \mathrm{Me}_{2} \mathrm{CO}$, respectively. Among them, elute the $40 \% \mathrm{MeOH}$ part in the Diaion column through Toyopearl HW-40 column chromato- graphy and repeatedly separate and purify by methanol-water resolvent system, we will get compound $\mathbf{9}(64 \mathrm{mg})$, compound 11 (116 mg).

\section{Determination of antioxidation activity}

Preparation for the sample solution: Weigh precisely a certain amount of synthetic antioxidants (Trolox). Mix it with the absolute ethyl alcohol to the constant volume of $25 \mathrm{~mL}$ we will get the solution- mass concentration value of $1.028 \mathrm{mg}$ $\mathrm{mL}^{-1}$ and then progressively dilute it into a series of solutions with different concentrations. Dissolve the 12 monomer compounds with the absolute ethyl alcohol and progressively dilute it into different concentrations.

Preparation for the DPPH solution: Weigh precisely $20.8 \mathrm{~g}$ of the DPPH reagent,and mix it with the absolute ethyl alcohol to the flask of the constant volume of $100 \mathrm{~mL}$. Shake it evenly and put into the refrigerator for future use. When it is ready for use, dilute the stored DPPH solution to the concentration of $42.8 \mathrm{mg} \mathrm{mL}^{-1}$.

Determination for the antioxidation: DPPH is a steady free radical in the organic reagents and its lone pair electrons have a strong absorption near $517 \mathrm{~nm}$ (appearing dark violet colour). When the scavenging agents exist, the lone pair electrons will be paired and its absorption will disappear or diminish. Through determining the absorption decreasing degree, the radical-scavenging activity can be evaluated ${ }^{2}$. Put, respectively the DPPH ethanol solution of $100 \mu \mathrm{L}$ into the $200 \mu \mathrm{L}$ sample solutions with different concentrations and place it peacefully for $20 \mathrm{~min}$ at the temperature of $24^{\circ} \mathrm{C}$ after shaking it evenly. Determine the adsorption power at $517 \mathrm{~nm}$ by the enzyme-labeled instrument and calculate the DPPH freeradical scavenging rate by the following equation:

Scavenging $\%=1-\left(\mathrm{A}_{\mathrm{p}}-\mathrm{A}_{\mathrm{c}}\right) / \mathrm{A}_{\max } \times 100 \%$

In this equation, $A_{p}$ is the adsorption power of the $200 \mu \mathrm{L}$ DPPH solution and the $100 \mu \mathrm{L}$ ready-for-determination solution, $A_{c}$ is the adsorption power of the $200 \mu \mathrm{L}$ readyfor-determination solution and the $100 \mu \mathrm{L}$ anhydrous ethanol, $\mathrm{A}_{\max }$ is the adsorption power of the $100 \mu \mathrm{L}$ DPPH solution and the $200 \mu \mathrm{L}$ anhydrous ethanol ${ }^{11}$.

\section{Determination for the antimicrobial activity}

Activating and sterilizing treatment of the bacteria strains: Put the colon bacillus and refrigerated strains of Staphylococcus aureus into 2 nutrient agar slant culturemedia, respectively and activate them at the temperature of $30{ }^{\circ} \mathrm{C}$ for $24 \mathrm{~h}$. The culture medium, related experimental apparatuses and the reagents are all sterilized for $2 \mathrm{~h}$ at the temperature of $120^{\circ} \mathrm{C}$ by high-pressure sterilization under the damp circumstances.

Preparation for the testing bacteria suspension liquid and the bacteria-contained plate: Take four test tubs with $10 \mathrm{~mL}$ sterile water and put them on the tube rack and choose 2 links from the two slanting pre-activated bacteria strains and dissolve them into 4 tubes of sterile water, respectively to make them into bacterial strain suspension liquids. Dilute the bacterial liquid and make it contain the bacteroids of $10^{7}-10^{8} \mathrm{cfu} \mathrm{L}^{-1}$ and we will get bacterial suspension liquid. And then pour the melted disinfecting culture medium into the sterile culture dish. After it solidifies, drip $0.1 \mathrm{~mL}$ bacterial suspension liquid and 
use sterile coating loops to spread the bacterial suspension liquid evenly to make it into a bacteria-contained plate for future use.

Antimicrobial experiment: The determination of the antimicrobial activity takes the method of agar-spreading filter paper. We can judge the antimicrobial activity according to the diameter of the antimicrobial loops. Soak the sterile filter paper (the diameter is $5.0 \mathrm{~mm}$ and oven-dried after sterilized by hot steam) into 6 different volatile dilution with different concentrations for $10 \mathrm{~h}$, paste them on the bacteria-contained plates after trickle-dried with each plate of 3 pieces and taking on the shape of the Chinese word "PIN" and then foster them in the constant-temperature incubator. Use the filter paper pasted only by diethyl ether as the blank control. Record the diameters of the antimicrobial loops. Repeat the experiment of each group for 3 times and take the average value of the experiment.

Determination for the minimal inhibitory concentration (MIC): Put the filter paper which has been soaked in the diluted solution of 12 monomer compounds into the plate contained with bacterial suspension liquid and observe them after cultivating for $24 \mathrm{~h}$, using the minimum solution concentration of the bacteria-free compound as the minimal inhibitory concentration (MIC).

\section{RESULTS AND DISCUSSION}

5-Hydroxy-7-methoxy sylflavanone (1): Compound 1, was obtained as white amorphous powder, m.p. $96-98^{\circ} \mathrm{C}$. The compound reveal fluorescence of amaranth in the $\mathrm{UV}_{254}$ and reveal blue with $\mathrm{FeCl}_{3}-\mathrm{K}_{3}\left[\mathrm{Fe}(\mathrm{CN})_{6}\right]$ reagent. EI-MS m/z: $270\left[\mathrm{M}^{+} .{ }^{1} \mathrm{H}\right.$ NMR $\left(400 \mathrm{MHz}, \mathrm{CDCl}_{3}\right) \delta: 7.82(2 \mathrm{H}, \mathrm{d}, J=8.4$ Hz, H-2',6'), 7.44 (2H, d, $J=8.4$ Hz, H-3',5'), 7.40(1H, dd, $J=$ $2.4 \mathrm{~Hz}, \mathrm{H}-4$ '), 7.08 (1H, d, $J=2.4 \mathrm{~Hz}, \mathrm{H}-8), 6.07$ (H, d, $J=2.4$ Hz, H-6), 5.43 (1H, dd, J = 12.0, 3.0 Hz, H-2), $3.10(1 \mathrm{H}$, dd, $J=16.0,12.0 \mathrm{~Hz}, \mathrm{H}-3), 2.82(1 \mathrm{H}, \mathrm{dd}, J=16.0,4.0 \mathrm{~Hz}, \mathrm{H}-3)$, $3.82\left(3 \mathrm{H}, \mathrm{s}, 7-\mathrm{OCH}_{3}\right) .{ }^{13} \mathrm{C} \mathrm{NMR}\left(100 \mathrm{MHz}, \mathrm{CDCl}_{3}\right) \delta: 79.2$ (C-2), 43.4 (C-3), 195.8 (C-4), 64.1 (C-5), 95.1 (C-6), 168.0 (C-7), 94.3 (C-8), 162.8 (C-9), 103.1 (C-10), 138.3 (C-1'), 126.1 (C-2', 6'), 128.9 (C-3',5'), 128.9 (C-4'), 55.7 (7- $\left.\mathrm{OCH}_{3}\right)$. The spectral data showed basically agreement with the literature $^{5}$, the compounds is 5-hydroxy-7-methoxy sylflavanone.

Chrysophanol (2): Compound 2, was obtained as a yellow crystalline, m.p. $194-196{ }^{\circ} \mathrm{C}$, the compound reveal fluorescence of amaranth in the $\mathrm{UV}_{254}$ and reveal blue with $\mathrm{FeCl}_{3}-\mathrm{K}_{3}\left[\mathrm{Fe}(\mathrm{CN})_{6}\right]$ reagent. ${ }^{1} \mathrm{H}$ NMR $\left(400 \mathrm{MHz}, \mathrm{CDCl}_{3}\right)$ the signals of five aromatic protons were exhibited at $\delta 7.28(1 \mathrm{H}$, s, H-2), 7.10 (1H, s, H-4), 7.65 (1H, dd, $J=8.4,7.6 \mathrm{~Hz}, \mathrm{H}-6$ ), $7.68(1 \mathrm{H}, \mathrm{d}, J=8.4 \mathrm{~Hz}, \mathrm{H}-5), 7.83(1 \mathrm{H}, \mathrm{d}, J=8.4 \mathrm{~Hz}, \mathrm{H}-7)$, d12.01 (1H, s, 1-OH), 12.12 (1H, s, 8-OH), 2147 (3H, s, 3$\left.\mathrm{CH}_{3}\right) .{ }^{13} \mathrm{C} \mathrm{NMR}\left(100 \mathrm{MHz}, \mathrm{CDCl}_{3}\right) \delta 162.8(\mathrm{C}-1), 124.6(\mathrm{C}-$ 2), 133.3 (C-3), 124.4 (C-4), 121.4 (C-5), 119.7 (C-6), 136.7 (C-7), 162.5 (C-8), 192.6 (C-9), 182.0 (C-10), 116.0 (C-11), 149.4 (C-12), 113.8 (C-13), 127.4 (C-14), 22.3 (C-15). The spectral data showed basically agreement with the literature ${ }^{6}$, the compounds is chrysophanol.

Juglone (3): Compound 3, was obtained as a yellow crystalline, m.p. $153-155^{\circ} \mathrm{C}$, it can be dissolved easily in the $\mathrm{CHCl}_{3}$ and EtOAc. ${ }^{1} \mathrm{H}$ NMR (300 MHz, $\left.\mathrm{CDCl}_{3}\right) \delta: 7.64(1 \mathrm{H}, \mathrm{d}, J=$
$7.5 \mathrm{~Hz}), 7.61(1 \mathrm{H}, \mathrm{d}, J=7.5 \mathrm{~Hz}), 6.95(1 \mathrm{H}, \mathrm{m}), 6.92(1 \mathrm{H}, \mathrm{m})$, $7.28(1 \mathrm{H}, \mathrm{m}) .{ }^{13} \mathrm{C} \mathrm{NMR}\left(80 \mathrm{MHz}, \mathrm{CDCl}_{3}\right) \delta: 184.41(-\mathrm{CO}-)$, 190.44 (-CO-), $\delta 190.4$ (C-1), 139.7 (C-2), 138.4 (C-3), 184.4 C-4), 161.6 (C-5), 124.7 (C-6), 119.3 (C-7), 136.7 (C-8), 131.9 (C-9), 115.1 (C-10). The spectral data showed basically agreement with the literature ${ }^{7}$, the compounds is Juglone.

4-Hydroxy-cinnamic acid methylester (4): Compound 4, was obtained as a colourless crystalline, it can be dissolved easily in the $\mathrm{CH}_{3} \mathrm{OH}$. The compound reveal fluorescence of amaranth in the $\mathrm{UV}_{254}$ and reveal blue with $\mathrm{FeCl}_{3}-\mathrm{K}_{3}\left[\mathrm{Fe}(\mathrm{CN})_{6}\right]$ reagent. ${ }^{1} \mathrm{H} \mathrm{NMR}\left(300 \mathrm{MHz}, \mathrm{CDCl}_{3}\right)$ there are four aromatic protons, $7.44(2 \mathrm{H}, \mathrm{d}, J=8.6 \mathrm{~Hz}), 6.80(2 \mathrm{H}, \mathrm{d}, J=8.4 \mathrm{~Hz})$ as an ABAB system. In addition, the ${ }^{1} \mathrm{H}$ NMR spectrum further showed that $\delta 6.31(1 \mathrm{H}, \mathrm{d}, J=16.0 \mathrm{~Hz}), 7.63(1 \mathrm{H}, \mathrm{d}, J=16.0$ $\mathrm{Hz}), \delta 3.71\left(1 \mathrm{H}, \mathrm{s},-\mathrm{OCH}_{3}\right) .{ }^{13} \mathrm{C} \mathrm{NMR}\left(80 \mathrm{MHz}, \mathrm{CDCl}_{3}\right) \delta$ : 169.7 (C-1), 114.9 (C-2), 146.6 (C-3), 127.2 (C-1'), 131.1 (C2'), 116.8 (C-3'), 161.3 (C-4'), 116.8 (C-5'), 131.1 (C-6'), 51.7 $\left(-\mathrm{OCH}_{3}\right)$. The spectral data showed basically agreement with the literature ${ }^{8}$, the compounds is 4-hydroxy-cinnamic acid methylester.

5,7-Dihydroxy-sylflavanone (5): Compound 5, was obtained as a colourless crystalline, the compound reveal fluorescence of amaranth in the $\mathrm{UV}_{254}$ and reveal blue with $\mathrm{FeCl}_{3}-\mathrm{K}_{3}\left[\mathrm{Fe}(\mathrm{CN})_{6}\right]$ reagent. ${ }^{1} \mathrm{H}$ NMR $\left(400 \mathrm{MHz}, \mathrm{CDCl}_{3}\right) \delta$ : $7.94\left(2 \mathrm{H}, \mathrm{d}, J=8.0 \mathrm{~Hz}, \mathrm{H}-2^{\prime}, 6^{\prime}\right), 7.65(2 \mathrm{H}, \mathrm{d}, J=8.0 \mathrm{~Hz}, \mathrm{H}-$ $\left.3^{\prime}, 5^{\prime}\right), 7.41\left(1 \mathrm{H}, \mathrm{dd}, J=2.4 \mathrm{~Hz}, \mathrm{H}-4^{\prime}\right), 7.13(1 \mathrm{H}, \mathrm{d}, J=2.0 \mathrm{~Hz}$, H-8), 6.26 (1H, d, $J=2.0 \mathrm{~Hz}, \mathrm{H}-6), 4.51(1 \mathrm{H}, \mathrm{dd}, J=12.0,3.0$ Hz, H-2), 2.89 (1H, dd, $J=16.0,12.0 \mathrm{~Hz}, \mathrm{H}-3), 2.75$ (1H, dd, $J=16.0,4.0 \mathrm{~Hz}, \mathrm{H}-3) .{ }^{13} \mathrm{C} \mathrm{NMR}\left(100 \mathrm{MHz}, \mathrm{CDCl}_{3}\right) \delta: 80.4$ (C-2), 46.7 (C-3), 196.3 (C-4), 66.3 (C-5), 96.6 (C-6), 167.4 (C-7), 95.9 (C-8), 161.1 (C-9), 102.4 (C-10), 139.3 (C-1'), $128.6\left(\mathrm{C}-2^{\prime}, 6^{\prime}\right), 124.6\left(\mathrm{C}-3^{\prime}, 5^{\prime}\right), 126.8\left(\mathrm{C}^{\prime}-4^{\prime}\right)$. The spectral data showed basically agreement with the literature ${ }^{9}$, the compounds is 5,7-dihydroxy-sylflavanone.

Vanillin (6): Compound 6, was obtained as a colourless crystalline, m.p. $82-84^{\circ} \mathrm{C}$, the compound reveal fluorescence of amaranth in the $\mathrm{UV}_{254}$ and reveal blue with $\mathrm{FeCl}_{3}$ $\mathrm{K}_{3}\left[\mathrm{Fe}(\mathrm{CN})_{6}\right]$ reagent. ${ }^{1} \mathrm{H} \mathrm{NMR}\left(400 \mathrm{MHz}, \mathrm{CDCl}_{3}\right) \delta: 7.04(1 \mathrm{H}$, $\mathrm{d}, J=8.0 \mathrm{~Hz}, \mathrm{H}-5), 7.43(1 \mathrm{H}, \mathrm{dd}, J=8.0,1.2 \mathrm{~Hz}, \mathrm{H}-6)$ and $7.42(1 \mathrm{H}, \mathrm{d}, J=1.2 \mathrm{~Hz}, \mathrm{H}-2)$ as an ABX system, $\delta 9.83(1 \mathrm{H}$, s, 4-OH). ${ }^{13} \mathrm{C}$ NMR $\left(100 \mathrm{MHz}, \mathrm{CDCl}_{3}\right) \delta: 129.9(\mathrm{C}-1), 127.6$ (C-2), 147.1 (C-3), 151.7 (C-4), 114.4 (C-5), 108.7 (C-6), 190.9 (C-CHO), $56.1\left(3-\mathrm{OCH}_{3}\right)$. The spectral data showed basically agreement with the literature ${ }^{10}$, the compounds is vanillin.

Kaempferol (7): Compound 7, was obtained as yellow amorphous powder, ${ }^{1} \mathrm{H}$ NMR (400 MHz, DMSO- $\left.d_{6}\right) \delta: 10.48$ (1H, s, 7-OH), $12.62(1 \mathrm{H}, \mathrm{s}, 5-\mathrm{OH}), 10.32(1 \mathrm{H}, \mathrm{s}, 3-\mathrm{OH}), 9.38$ (1H, s, 4'-OH), 7. 67 (2H, d, J = 8.2 Hz, H-2', 6'), $6.89(2 \mathrm{H}, \mathrm{d}$, $\left.J=8.2 \mathrm{~Hz}, \mathrm{H}-3^{\prime}, 5^{\prime}\right), 6.32(1 \mathrm{H}, \mathrm{d}, J=2.4 \mathrm{~Hz}, \mathrm{H}-8), 6.18(1 \mathrm{H}$, $\mathrm{d}, J=2.4 \mathrm{~Hz}, \mathrm{H}-6) .{ }^{13} \mathrm{C}$ NMR (DMSO- $\left.d_{6}, 100 \mathrm{MHz}\right) \delta: 178.16$ (C-4), 164.71 (C-7), 161.87 (C-9), 160.33 (C-4'), 158.04 (C5), 147.59 (C-2), 137.84 (C-3), 130.57 (C-2', C-6'), 116.78 (C-3', C-5'), 122.78 (C-1'), 104.56 (C-10), 99.35 (C-6), 95.65 (C-8). The spectral data showed basically agreement with the literature $^{11}$, the compounds is kaempferol.

Vanillic acid (8): Compound 8, was obtained as a white crystalline, ${ }^{1} \mathrm{H} \mathrm{NMR}\left(400 \mathrm{MHz}, \mathrm{CDCl}_{3}\right) \delta: 3.83\left(3 \mathrm{H}, \mathrm{s}, \mathrm{OCH}_{3}\right)$, 
$6.81(1 \mathrm{H}, \mathrm{dd}, J=1.6,8.2 \mathrm{~Hz}, \mathrm{H}-6), 7.21$ (2H, m, H-2,5), 9.68 $(1 \mathrm{H}, \mathrm{s}, 4-\mathrm{OH}), 12.10(1 \mathrm{H}$, br s, $-\mathrm{COOH}) .{ }^{13} \mathrm{C} \mathrm{NMR}(100 \mathrm{MHz}$, $\left.\mathrm{CDCl}_{3}\right) \delta: 120.2(\mathrm{C}-1), 115.2(\mathrm{C}-2), 145.2(\mathrm{C}-3), 152.2(\mathrm{C}-4)$, 113.7 (C-5), 124.8 (C-6), $168.4-\mathrm{COOH}), 55.3\left(-\mathrm{OCH}_{3}\right)$. The spectral data showed basically agreement with the literature ${ }^{12}$, the compounds is vanillic acid.

Chlorogenic acid (9): Compound 9, was obtained as a white amorphous powder, it can be dissolved easily in the $\mathrm{MeOH}$. The compound reveal fluorescence of amaranth in the $\mathrm{UV}_{254}$ and reveal blue with $\mathrm{FeCl}_{3}-\mathrm{K}_{3}\left[\mathrm{Fe}(\mathrm{CN})_{6}\right]$ reagent. ${ }^{1} \mathrm{H}$ NMR (400 MHz, MeOD) showed that $\delta: 6.31(1 \mathrm{H}, \mathrm{d}, J=15.9$ Hz, H-2'), 7.59 (1H, d, $J=15.9$ Hz, H-3'), 6.77(1H, d, $J=8.1$ Hz, H-8'), $\delta 6.94$ (1H, dd, $\left.J=1.8,8.1 \mathrm{~Hz}, \mathrm{H}-9^{\prime}\right), \delta 7.05$ (1H, d, $\left.J=1.8 \mathrm{~Hz}, \mathrm{H}-5^{\prime}\right)$ as an ABX system. $1.96(2 \mathrm{H}, \mathrm{m}, \mathrm{H}-2), 4.15$ (1H, m, H-3), 3.65 (1H, m, H-4), 4.18 (1H, m, H-5), 1.98 (1H, q, H-6), 2.16 (1H, m, H-6). ${ }^{13} \mathrm{C}$ NMR (100 MHz, MeOD) $\delta$ : 169.0 (C-1'), 116.5 (C-2'), 146.8 (C-3'), 128.0 (C-4'), 115.8 (C-5'), 149.4 (C-6'), 149.4 (C-7'), 115.1 (C-8'), 124.1 (C-9'), 75.4 (C-1), 41.5 (C-2), 68.3 (C-3), 74.8 (C-4), 73.0 (C-5), 56.7 (C-6), 178.1 (C-7). The spectral data showed basically agreement with the literature ${ }^{13}$. The melting point of the mixture (the sample and the standard substance) does not drop. The sample and the standard substance have the same $\mathrm{R}_{\mathrm{f}}$ value, the compounds is chlorogenic acid.

Cinnamic acid (10): Compound 10, was obtained as a white amorphous powder, ${ }^{1} \mathrm{H} \mathrm{NMR}\left(400 \mathrm{MHz}, \mathrm{CDCl}_{3}\right) \delta: 6.94$ $(1 \mathrm{H}, \mathrm{d}, J=16.0 \mathrm{~Hz}, \mathrm{H}-8), 7.84(1 \mathrm{H}, \mathrm{d}, J=16.0 \mathrm{~Hz}, \mathrm{H}-7),(3 \mathrm{H}$, $\mathrm{m}, \mathrm{H}-3,4,5), 7.72$ (2H, m, H-2, 6). ${ }^{13} \mathrm{C}$ NMR (100 MHz, $\left.\mathrm{CDCl}_{3}\right)$ \&: $135.6(\mathrm{C}-1), 129.1(\mathrm{C}-2,6), 130.5(\mathrm{C}-3,5), 131.5$ (C-4), 145.6 (C-7), 120.8 (C-8), 168.2 (C-9). The spectral data showed basically agreement with the literature ${ }^{14}$, the melting point of the mixture (the sample and the standard substance) does not drop. The sample and the standard substance have the same $R_{f}$ value, the compounds is cinnamic acid.

4-Hydroxy-3-methoxy benzyl- $\beta$-D-glucoside (11): Compound 11, was obtained as a white crystalline, it can be dissolved easily in the $\mathrm{MeOH}$ and $\mathrm{Me}_{2} \mathrm{CO}$. The compound reveal fluorescence of amaranth in the $\mathrm{UV}_{254}$ and reveal blue with $\mathrm{FeCl}_{3}-\mathrm{K}_{3}\left[\mathrm{Fe}(\mathrm{CN})_{6}\right]$ reagent. $\mathrm{HCl}-\mathrm{Mg}$ reaction reveal masculine, acid hydrolysis gave glucose, identified by TLC. ${ }^{1} \mathrm{H}$ NMR (300 MHz, MeOD) there are three aromatic protons, $\delta 6.77(1 \mathrm{H}, \mathrm{d}, J=8.1 \mathrm{~Hz}), 7.00(1 \mathrm{H}, \mathrm{d}, J=8.0 \mathrm{~Hz})$ and 6.82 $(1 \mathrm{H}, \mathrm{s})$ as an $\mathrm{ABX}$ system, $\delta 3.74\left(2 \mathrm{H}, \mathrm{s},-\mathrm{OCH}_{2^{-}}\right), 3.81(3 \mathrm{H}$, $\left.\mathrm{s},-\mathrm{OCH}_{3}\right), \delta 3.37-4.67$ are seven protons signal of $\mathrm{D}$-glycose. ${ }^{13} \mathrm{C}$ NMR (80 MHz, MeOD) $\delta 133.5$ (C-1), 116.0 (C-2), 149.0 (C-3), 147.9 (C-4), 111.6 (C-5), 120.9 (C-6), 105.3 (C-1'), 87.7 (C-2'), 78.0 (C-3'), 75.3 (C-4'), 71.4 (C-5'), 62.8 (C-6'), $56.41\left(-\mathrm{OCH}_{3}\right)$. The spectral data showed basically agreement with the literature ${ }^{15}$, the compounds is 4-hydroxy-3-methoxy benzyl- $\beta$-D-glucoside.

4-Hydroxy-cinnamic acid ethylester (12): Compound 12, was obtained as a colourless crystalline, it can be dissolved easily in the $\mathrm{MeOH}$, the compound reveal fluorescence of amaranth in the $\mathrm{UV}_{254}$ and reveal blue with $\mathrm{FeCl}_{3}-\mathrm{K}_{3}\left[\mathrm{Fe}(\mathrm{CN})_{6}\right]$ reagent. ${ }^{1} \mathrm{H} \mathrm{NMR}\left(300 \mathrm{MHz}, \mathrm{CDCl}_{3}\right)$ there are four aromatic protons, $7.59(2 \mathrm{H}, \mathrm{d}, J=8.6 \mathrm{~Hz}), 6.75(2 \mathrm{H}, \mathrm{d}, J=7.2 \mathrm{~Hz})$ as an AABB system. $\delta: 6.29(1 \mathrm{H}, \mathrm{d}, J=12.8 \mathrm{~Hz}), 7.58(1 \mathrm{H}, \mathrm{d}, J=$ $12.8 \mathrm{~Hz}), 3.58\left(2 \mathrm{H}, \mathrm{m},-\mathrm{OCH}_{2}-\right), 1.28\left(2 \mathrm{H}, \mathrm{m},-\mathrm{CH}_{3}\right) .{ }^{13} \mathrm{C} \mathrm{NMR}$

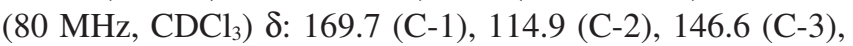

127.2 (C-1'), 131.1 (C-2'), 116.8 (C-3'), 161.3 (C-4'), 116.8 $\left(\mathrm{C}^{-} 5^{\prime}\right), 131.1\left(\mathrm{C}-6^{\prime}\right), 51.7\left(-\mathrm{OCH}_{2}-\right), 18.7\left(-\mathrm{CH}_{3}\right)$. The spectral data showed basically agreement with the literature ${ }^{16}$, the compounds is 4-hydroxy-cinnamic acid ethylester.

Results for the antioxidating activity: $\mathrm{IC}_{50}$ value is a commonly used parameter for evaluating the antioxidating power, which refers to the required concentration when the antioxidants scavenge the free radicals of $50 \% \mathrm{DPPH}$. When reaching $50 \%$ scavenging rate, the smaller its value, the less amount of the free-radical scavenging agents and the better effect of the scavenging result and stronger the correspondent antioxidating activity of the tested samples. According to the above method, we can determine the scavenging results of the 12 monomer compounds for DPPH, which can be seen from Table-1. As can be seen from Table-1, all of the 12 compounds have a certain power of antioxidation and with the rising of the compound concentration and the increasing scavenging rate, it is clear that the compound $\mathbf{7}$ has the most powerful antioxidating activity, the next are compound $\mathbf{2}$, compound $\mathbf{5}$ and compound 11, with compound $\mathbf{1 0}$ being the smallest antioxidating activity.

\begin{tabular}{lccc}
\multicolumn{4}{c}{ TABLE-1 } \\
$\begin{array}{l}\text { ANTIOXIDATIVE ACTIVITY OF THE TWELVE } \\
\text { COMPOUNDS GIVEN AS IC }\end{array}$ 泟 VALUES \\
\hline \multicolumn{1}{c}{ Samples } & Regression equation & $\mathrm{R}^{2}$ & $\begin{array}{c}\mathrm{IC}_{50} \\
\left(\mu \mathrm{gL}^{-1}\right)\end{array}$ \\
\hline Compound 1 & $\mathrm{y}=1.3454 \mathrm{x}+0.4688$ & 0.9985 & 39.65 \\
Compound 2 & $\mathrm{y}=0.6817 \mathrm{x}+1.8532$ & 0.9889 & 26.56 \\
Compound 3 & $\mathrm{y}=0.8435 \mathrm{x}+0.8535$ & 0.9743 & 38.43 \\
Compound 4 & $\mathrm{y}=3.6544 \mathrm{x}+7.7423$ & 0.9677 & 64.47 \\
Compound 5 & $\mathrm{y}=2.4896 \mathrm{x}+3.8540$ & 0.9891 & 28.56 \\
Compound 6 & $\mathrm{y}=1.2876 \mathrm{x}+0.4290$ & 0.9923 & 42.29 \\
Compound 7 & $\mathrm{y}=0.4980 \mathrm{x}+5.6729$ & 0.9716 & 21.14 \\
Compound $\mathbf{8}$ & $\mathrm{y}=6.5528 \mathrm{x}+7.9013$ & 0.9923 & 40.56 \\
Compound 9 & $\mathrm{y}=5.2091 \mathrm{x}+0.4198$ & 0.9985 & 39.10 \\
Compound 10 & $\mathrm{y}=1.9065 \mathrm{x}+3.7134$ & 0.9665 & 127.29 \\
Compound 11 & $\mathrm{y}=6.8467 \mathrm{x}+9.3267$ & 0.9744 & 30.88 \\
Compound 12 & $\mathrm{y}=2.0567 \mathrm{x}+5.7817$ & 0.9823 & 56.32 \\
Trolox & $\mathrm{y}=0.6682 \mathrm{x}+2.7745$ & 0.9844 & 18.4 \\
\hline
\end{tabular}

Results of antimicrobial: The results of the MIC of the 12 monomer compounds for Staphylococcus aureus and Colon bacillus standard strains as well as its antiseptic power are shown in Table-2. The results show that the 12 monomer compounds have a clear prohibitory action on the two tested bacteria strains and with the increasing of the compound concentration, the prohibitory action becomes stronger. But the different compounds have different prohibitory actions on the growth of the two bacteria. The compound $\mathbf{7}$ and $\mathbf{9}$ have strong antimicrobial activity on Staphylococcus epdermidis, whereas the antimicrobial activity of compounds $\mathbf{1 0}$ and $\mathbf{1 2}$ is not obvious. Compounds $\mathbf{1}$ and $\mathbf{7}$ have a clear effect on prohibiting Colon bacillus, whereas the antimicrobial activity of compounds $\mathbf{4 , 1 0}$ and $\mathbf{1 2}$ is not obvious.

\section{Conclusion}

Through the above systematic separation by extraction for the pecan epicarps, twelve monomer compounds are determined by separation. Among them, compounds 6-12 are first obtained from these plants by separation. At the same 


\begin{tabular}{lcc}
\hline \multicolumn{3}{c}{$\begin{array}{c}\text { TABLE-2 } \\
\text { ANTIMICROBIAL ACTIVITY OF THE TWELVE } \\
\text { SAMPLES GIVEN AS INHIBITION ZONE }\end{array}$} \\
\hline Sample & $\begin{array}{c}\text { MIC of Colon bacillus } \\
\left(\mu \mathrm{g} \mathrm{m}^{-1}\right)\end{array}$ & $\begin{array}{c}\text { MIC of Staphylococcus } \\
\text { epdermidis }\left(\mu \mathrm{mL}^{-1}\right)\end{array}$ \\
\hline Compound $\mathbf{1}$ & 0.78 & 6.25 \\
Compound $\mathbf{2}$ & 3.13 & 12.50 \\
Compound $\mathbf{3}$ & 12.50 & 25.00 \\
Compound $\mathbf{4}$ & 100.00 & 6.25 \\
Compound $\mathbf{5}$ & 6.25 & 25.00 \\
Compound $\mathbf{6}$ & 12.50 & 6.25 \\
Compound $\mathbf{7}$ & 1.56 & 0.39 \\
Compound $\mathbf{8}$ & 25.00 & 12.50 \\
Compound $\mathbf{9}$ & 12.50 & 0.78 \\
Compound $\mathbf{1 0}$ & 50.00 & 200.00 \\
Compound $\mathbf{1 1}$ & 12.50 & 25.00 \\
Compound $\mathbf{1 2}$ & 50.00 & 100.00 \\
\hline${ }^{\mathrm{a}}$ Mean value, $\mathrm{n}=3$ (as & the diameter of the disk was $5.0 \mathrm{~mm}$.
\end{tabular}

${ }^{a}$ Mean value, $\mathrm{n}=3$ (as the diameter of the disk was $5.0 \mathrm{~mm}$ ). (Measured in $\mathrm{mm})^{\mathrm{a}}$.

time, the authors conducted an antioxidation activity determination for the 12 monomer compounds. The results of the determination show that the 12 monomer compounds have a certain prohibitory action and with the increasing of the compound concentration, the scavenging rate rises and among them, the compound $\mathbf{7}$ has the strongest antioxidation activity, next are compounds $\mathbf{2 , 5}$ and $\mathbf{1 1}$ with compound $\mathbf{1 0}$ the smallest antioxidation activity. All of the 12 compounds also have a certain power of antiseptic activity and it is clear that the compounds $\mathbf{7}$ and 9 have the most powerful antimicrobial activity on Staphylococcus epdermidis, whereas the antimicrobial activity of compounds $\mathbf{1 0}$ and $\mathbf{1 2}$ is not clear; compounds $\mathbf{1}$ and $\mathbf{7}$ have an obvious antiseptic action on Colon bacillus, while the antimicrobial activity on colon bacillus of compounds 4, 10 and 12 is not clear.

\section{ACKNOWLEDGEMENTS}

The authors are grateful to the Center of Analysis and Testing, Zhengzhou University, for performing the NMR data. Thanks are also due to Zhejiang Provincial Key Laboratory for Modern Silvicultural Technology, Zhejiang Agriculture and Forestry University for performing Universal Microplate Spectrophotometer. This project is sponsored by Zhejiang Provincial Natural Science Foundation of China (Y2111140).

\section{REFERENCES}

1. J.Q. Huang, W. Fang, Y.L. Ding and F.J. He, J. Zhejiang Forestry College, 19, 227 (2002).

2. H.Y. Yao, J.C. Tang, A.L. Zhang and Y.P. Xu, Acta Bot. Boreal-Occident Sin., 23, 1650 (2003).

3. J.H. Shi, J.H. Wang, D. Che, Y.R. Song and X. Li, Res. Inform. Fradit. Chin. Med., 7, 7 (2005).

4. K. Yuan and L. Yu, Chin. J. Anal. Chem., 33, 1358 (2005).

5. D.L. Wu, S.Y. Chen, J.S. Liu, C.S. Jin and F.Q. Xu, J. Chin. Med. Mater., 34, 1055 (2011).

6. J.L. Kuang and D.Z. Zhang, J. Guangdong College Pharm., 23, 1221 (2007).

7. J.L. Wang, S.X. Zhang, T.J. Li, W.Q. Zhang, J.J. Wang and S.J. Zhang, Chin. Trad. Herbal Drugs, 39, 490 (2008).

8. Y.H. Liu, W.T. Qiao, Z.F. Cheng and K. Yuan, Chin. Trad. Herbal Drugs, 40, 1359 (2009).

9. X.Q. Li, P.F. Zhang, W.D. Duan, D.L. Zhang and C. Li. J. Chin. Med. Mater, 32, 1227 (2009).

10. X.M. Wang, Y.C. Luo, Z.Y. Guo, D. Cao, M.X. Zhou, Y.Y. Zhao, K. Zou and Y.Z. Wang, J. Chin. Med. Mater, 34, 891 (2011).

11. X.J. Wu, J.X. Song, A.H. Zhao and W. Jia, Nat. Prod. Res. Dev., 23, $556(2011)$

12. X.J. Wang, Y.X. Zhao, X.H. Jia and X.B. Ding, J. Chin. Med. Mater, 34, 230 (2011).

13. K. Yuan, A. Jia and J.X. Zhu, Chin. J. Anal. Chem., 36, 47 (2008).

14. Q.H. Wang, X.L. Wu and J.H. Wang, Chin. Trad. Herbal Drugs, 42 , 1075 (2011).

15. K. Machida, Y. Yogiashi, S. Matsuda and A. Suzuki, Nat. Med. (Tokyo), 63, 220 (2009).

16. M.T. Xiao, J. Ye, B.B. Hong, K. Zan and P.F. Tu, Chin. Pharm. J., 46, 414 (2011). 